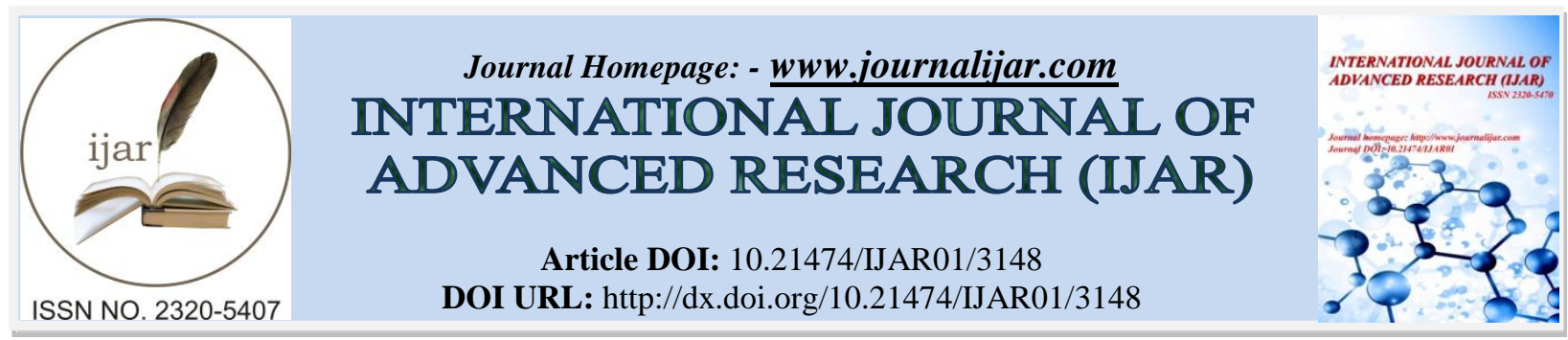

RESEARCH ARTICLE

\title{
THE CORPORATE IMAGE AND ITS IMPACT IN THE PURCHASE DECISION STUDY IN ORASCOM TELECOM CORPORATION DJEZZY BECHAR - ALGERIA.
}

\section{Ilyes Slimani, Souad Douli and Abdeljalil Mokaddem.}

Laboratory of study economics \& development local in south west of Algeria department of management, university of bechar, Algeria.

\section{Manuscript Info}

Manuscript History

Received: 05 December 2016

Final Accepted: 13 January 2017

Published: February 2017

Key words:-

Consumer behavior; resolution purchasing,

Orascom Telecom Corporation Djezzy,

corporate image.

\begin{abstract}
This study aimed to identify the relationship between company image and Purchasing decision at Orascom Telecom Djezzy in Béchar. The study identifies a community of mobile services users in Béchar "Djezzy Foundation was chosen as a sample of them reached their size (26) customer, for completion of this study, we prepared a questionnaire composed of three sections : Devoted the first part of personal information, the second of them Factors affecting the Enterprise image consists of 12 questions, and Part III ;Purchasing decision consists of (07) question, was this relationship is tested using spss 19 statistical program, there is no impact to the image of the institution on the decision of purchasing for the consumer, And there is found a set of recommendations that can help your organization to adopt this important element
\end{abstract}

Copy Right, IJAR, 2017,. All rights reserved.

\section{Introduction:-}

Value judgment made by an individual on a company (corporate image), brand (brand image), a product (product image) or a person (personal image). Part of the value of a brand, it is the combination of actual values of received ideas, emotional feelings, impressions, objective, subjective, conscious or unconscious, and the personality of the brand, the product of the individual or the company. The term 'goodwill' is sometimes used to denote the image of a company, the degree of confidence that bring clients and consumers of its products. However, should not confuse branding with the brand identity. Christian Michon explains in this regard that: "the concept of identity is fundamentally different from the concept of branding. The identity is part of a context more wide of the company and its history as a source of communication. Brand has as a key source of perception: the product, its attributes and advertising.

The problem of the study" :

What is the effect of company image on Purchase Decision IN Orascom Telecom institution "jazzy" Béchar Algeria-

\section{Hypotheses:-}

$>$ There is a positive relationship between the corporate image and Purchase Decision.

$>$ There are significant relationship between personal factors and the Purchase Decision.

$>$ There are significant relationship between Social factors and the Purchase Decision.

$>$ There are significant relationship between Organizational factors and the Purchase Decision.

$>$ There are significant relationship between informational factors and the Purchase Decision 


\section{Objectives of the study:-}

$>$ Knowledge of how to measure the company's image, and how they are configured and improvement;

$>$ determine the effect of the company's image on Purchase Decision.

\section{Corporate image and Purchase Decision:-}

Some terms are so basic to a discipline that it is difficult to define them using only other terminology from within a discipline. The concept of corporate image is one such foundational term. The purpose of this paper is to review the various definitions of corporate image which have been proposed over the years and to attempt to develop a synthesis. A model is developed to differentiate among the concepts of corporate personality, corporate identity and company image. A special emphasis is placed on identifying the dimensions which underlie corporate image. Recommendations are made for measuring this important concept, depending upon the stakeholder group of interest to the researcher.

Mental picture that springs up at the mention of a firm's name. It is a composite psychological impression that continually changes with the firm's circumstances, media coverage, performance, pronouncements, etc. Similar to a firm's reputation or goodwill, it is the public perception of the firm rather than a reflection of its actual state or position. Unlike corporate identity, it is fluid and can change overnight from positive to negative to neutral. Large firms use various corporate advertising techniques to enhance their image in order to improve their desirability as a supplier, employer, customer, borrower, etc. ${ }^{i}$

\section{The Definition of corporate image:-}

The perception people have of your business when they hear your company name. A business's image is composed of an infinite variety of facts, events, personal histories, advertising and goals that work together to make an impression on the public

Corporate image and reputation is considered to be a critical factor in the overall evaluation of any organization (Bitner, 1990, 1991; Gronroos, 1984; Gummesson and Gronroos, 1998; Andreassen and Lanseng, 1997; Andreassen and Lindestad, 1998; Kandampully and Hu, 2007; Sarstedt et al., 2012) because of the strength that lies in the customers' perception and mind when hearing the name of the organization (Fombrun, 1996; Hatch et al., 2003; Nguyen, 2006; Bravo et al., 2009). Thus, continuous research on corporate image and reputation is a must for those organizations that want to successfully differentiate their positioning in the market. ${ }^{i i}$

Companies' increasing concern about their image, identity and culture must be seen in relation to a number of changes that influence their roles and opportunities. Today, the information we receive is no longer scarce; actually the amount of information is drowning us. This abundance has created much confusion. Demand and supply for information are disoriented and, thus, become increasingly dependent on the guidelines and criteria for sorting information in order to reduce confusion. Orientation is less and less a matter of gathering information and more and more a matter of sorting and connecting. The company's consumers, stakeholders and employees are all influenced by this development.

\section{The Definition of Purchase Decision:-}

The decision of buying an item does not instantly take place. Behind the visible act of purchasing an item, stands a buying decision process that smart companies should investigate. Motivation,

perception, learning, memory, personality, and attitude play an important role in the unfolding of the decision process that presupposes the consumer's covering of five stages: problem recognition, information search, evaluation of alternatives, purchase decision, and post purchase behaviour.

Marketers' task is to study consumer behaviour in order to achieve a thorough understanding of all five stages unfolding in this process, not only of the purchase decision as such. Buying behavior differs greatly depending on the purchased item, therefore, the types of decision behaviour need to be known and studied. They are: complex buying behaviour, dissonance-reducing buying behaviour, habitual buying behaviour, variety-seeking buying behaviour $^{\text {iv }}$

\section{Actors Affecting in corporate image:-}

the factors affecting the mental image of the institution in the following points: 
- Personal factors.

- $\quad$ social factors:

- organizational factors:

- informational factors

\section{Research questions and Model of the study:-}

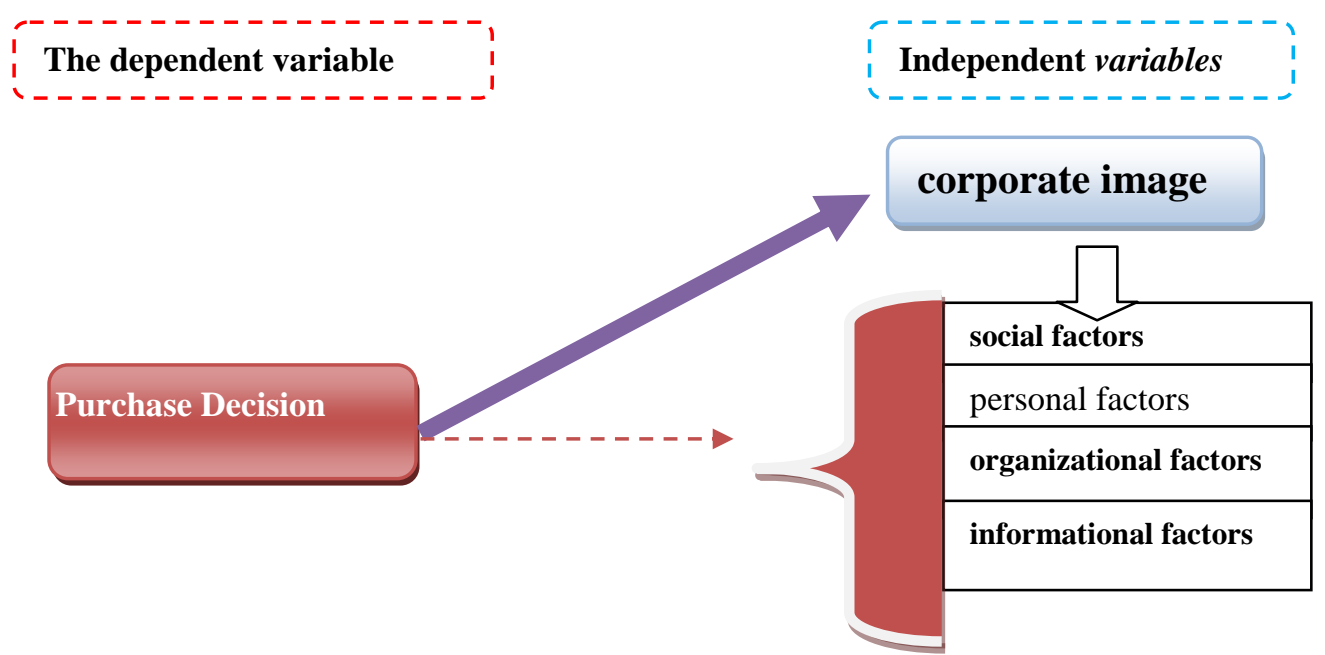

Figure 1:- Model of the study

\section{Study Design:-}

This study aimed to identify the relationship between company image and Purchasing decision at Orascom Telecom Djezzy in Béchar. The study identifies a community of mobile services users in Bechar "Djezzy Foundation was chosen as a sample of them reached their size (26) customer, for completion of this study, we prepared a questionnaire composed of three sections : Devoted the first part of personal information, the second of them Factors affecting the Enterprise image consists of 12 questions, and Part III ;Purchasing decision consists of (07) question, was this relationship is tested using spss 19 statistical program, there is no impact to the image of the institution on the decision of purchasing for the consumer, And there is found a set of recommendations that can help your organization to adopt this important element

We used to divide the Likert where it meets every question from the axis of the questionnaire five options divided into grades as follows:

\begin{tabular}{|c|c|c|c|c|}
\hline class V & Fourth class & third-class & second-class & First-class \\
\hline Acceptable strongly & Acceptable & balanced & not agree & Strongly isagree \\
\hline
\end{tabular}

\section{Results of the study data analysis and hypothesis testing:-}

Data analysis:-

Table 1:- Demographic Data of Samples

\begin{tabular}{|l|l|l|l|}
\hline \multicolumn{2}{|c|}{} & Choices & $\%$ \\
\hline \multirow{5}{*}{ Gender } & Male & 17 & 65.4 \\
\cline { 2 - 4 } & Female & 9 & 34.6 \\
\cline { 2 - 4 } & Total & 26 & 100.0 \\
\hline \multirow{5}{*}{ Age } & Lessthan30years & 6 & 23.1 \\
\cline { 2 - 4 } & 31 to lessthan40years & 17 & 65.4 \\
\cline { 2 - 4 } & 41 to lessthan55years & 3 & 11.5 \\
\cline { 2 - 4 } & 56years and over & 0 & 100.0 \\
\cline { 2 - 4 } & Total & 26 & 23.1 \\
\hline \multirow{5}{*}{ Qualification } & Secondary & 7 & 26.9 \\
\cline { 2 - 3 } & Academic & 17 & 65.4 \\
\cline { 2 - 3 } & Graduate Studies & 2 & 7.7 \\
\hline
\end{tabular}




\begin{tabular}{|l|l|l|l|}
\hline \multirow{4}{*}{ Work Experience } & Total & 26 & 100.0 \\
\cline { 2 - 4 } & 1 to lessthan4years & 6 & 23.1 \\
\cline { 2 - 4 } & 5 to lessthan10years & 17 & 65.4 \\
\cline { 2 - 4 } & 11 to lessthan13years & 3 & 11.5 \\
\cline { 2 - 4 } & Total & 26 & 100.0 \\
\hline Fonction & Director of the Département & 2 & 7.7 \\
\cline { 2 - 4 } & Senior management & 4 & 15.4 \\
\cline { 2 - 4 } & Executive management & 17 & 65.4 \\
\cline { 2 - 4 } & Other Functions & 3 & 11.5 \\
\cline { 2 - 4 } & Total & 26 & 100.0 \\
\hline
\end{tabular}

Source: the preparation of researchers and the adoption of the spss 19.

Test the hypotheses of the study:-

First hypothesis: the effect of personal factors on the buying decision:-

H0: There are no significant differences between the personal factors and decision-purchasing relationship.

H1: There are significant differences between personal factors and decision-purchasing relationship.

Table 2:- The results of the measurement The effect of personal factors on the buying decision.

\begin{tabular}{|c|c|c|c|c|c|c|}
\hline $\begin{array}{c}\text { Independent } \\
\text { variables } \\
\text { The personal } \\
\text { factors }\end{array}$ & $\begin{array}{c}\text { The } \\
\text { correlation } \\
\text { coefficient }\end{array}$ & \multirow{2}{*}{$\begin{array}{c}\text { The regression } \\
\text { line }\end{array}$} & \multicolumn{4}{|c|}{ The variable décision-purchasing } \\
\cline { 4 - 7 } & $\mathbf{0 . 0 5 7}$ & $\mathbf{3 . 4 7 4}$ & $\mathbf{R}$ & $\mathbf{R 2}$ & $\mathbf{F}$ & sig \\
\hline
\end{tabular}

Source: the preparation of researchers and the adoption of the spss 19 .

When the value of freedom Degree $(13.28)=2.391$

Analysis: The above table shows that the bilateral link value $(\mathrm{R})$ between personal factors and decision SPV was (0.057), an increase of $(5.7 \%)$ is a very weak link, as was the coefficient of determination $(\mathrm{R} 2=0.003)$ that is $(0.3 \%)$ of change SPV in the decision due to the change in the personal factors. Note that the significance level (Sig 0.683 ) is greater than the level of significance $(0.05)$ This shows that there is no statistically significant differences between the decision SPV and personal factors, I accept the hypothesis of bad and reject the alternative hypothesis which there are no statistically significant differences between the decision relationship SPV and personal factors and thus can be written regression equation between personal factors (x1) and decision SPV (y) as follows:

$$
Y=3.474+0.057 X_{1}
$$

\section{Second Hypothesis : the relationship between social factors and buying decision:-}

H0: There is no statistically significant relationship between social factors and the purchasing decision.

H1: no statistically significant relationship between social factors and the purchasing decision.

Table 3:- Results of measuring the relationship between social factors and the buying decision

\begin{tabular}{|l|l|l|l|l|l|l|}
\hline \multirow{2}{*}{$\begin{array}{l}\text { Independent } \\
\text { variables } \\
\text { The social factors }\end{array}$} & $\begin{array}{l}\text { The } \\
\text { correlation } \\
\text { coefficient }\end{array}$ & The regression & \multicolumn{4}{|l|}{ The variable décision-purchasing } \\
\cline { 2 - 7 } & 0.058 & 3.265 & $\mathbf{R}$ & $\mathbf{R 2}$ & $\mathbf{F}$ & sig \\
\cline { 3 - 7 } & & 0.067 & $\mathbf{0 . 0 0 3}$ & 2.202 & 0.643 \\
\hline
\end{tabular}

Source: the preparation of researchers and the adoption of the spss 19 .

The above table shows that the bilateral link value (R) between social factors and decision SPV was (0.067), an increase of $(6.7 \%)$ is a very weak link, as was the coefficient of determination $(\mathrm{R} 2=0.003)$ that is $(0.4 \%)$ of change SPV in the decision due to the change in social factors. Note that the significance level (Sig 0.643) is greater than the level of significance (0.05) This shows that there is no statistically significant differences between the decision SPV and social factors, I accept the hypothesis of bad and reject the alternative hypothesis which there are no statistically significant differences between the decision relationship SPV and social factors and therefore can be written regression equation between social factors (x2) and the decision SPV (y) as follows

$$
Y=3.265+0.058 X_{2}
$$


The third hypothesis: the relationship between organizational factors and purchasing decision.

H0: There is no significant relationship between organizational factors and purchasing decision.

H1:There are significant differences between organizational factors and decision-purchasing relationship

Table 4:- The results of measuring the relationship between organizational factors and purchasing decision

\begin{tabular}{|c|c|c|c|c|c|c|}
\hline \multirow{3}{*}{$\begin{array}{l}\text { Independent variables } \\
\text { The organizational factors }\end{array}$} & \multirow{2}{*}{$\begin{array}{l}\text { The } \\
\text { correlation } \\
\text { coefficient }\end{array}$} & \multirow{2}{*}{$\begin{array}{l}\text { The regression } \\
\text { line }\end{array}$} & \multicolumn{4}{|c|}{ The variable décision-purchasing } \\
\hline & & & $\mathbf{R}$ & $\mathbf{R 2}$ & $\mathbf{F}$ & sig \\
\hline & -0.077 & 3.935 & 0.097 & 0.009 & 12.277 & 0.503 \\
\hline
\end{tabular}

Source: the preparation of researchers and the adoption of the spss 19.

Comment: The above table shows that the bilateral link value (R) between social factors and decision SPV was (0.097), an increase of $(9.7 \%)$ is a very weak link, as was the coefficient of determination $(\mathrm{R} 2=0.009)$ that is $(0.9 \%)$ of change SPV in the decision due to the change in regulatory factors. Note that the significance level (Sig0.503) is greater than the level of significance (0.05) This shows that there is no statistically significant differences between the purchasing decision and organizational factors differences, we accept the hypothesis of bad and reject any alternative hypothesis there is no statistically significant relationship between purchasing decision and organizational factors and thus can be written regression equation between organizational factors $(\mathrm{x} 3)$ and the decision SPV (y) as follows:

$$
Y=3.935-0.077 X_{3}
$$

The fourth hypothesis: the relationship between the informational factors on the buying decision.

H0: There is no statistically significant relationship between informational factors on purchasing decision.

H1: no statistically significant relationship between informational factors on purchasing decision.

Table 5:- Results of measuring the relationship between the informational factors on the buying decision

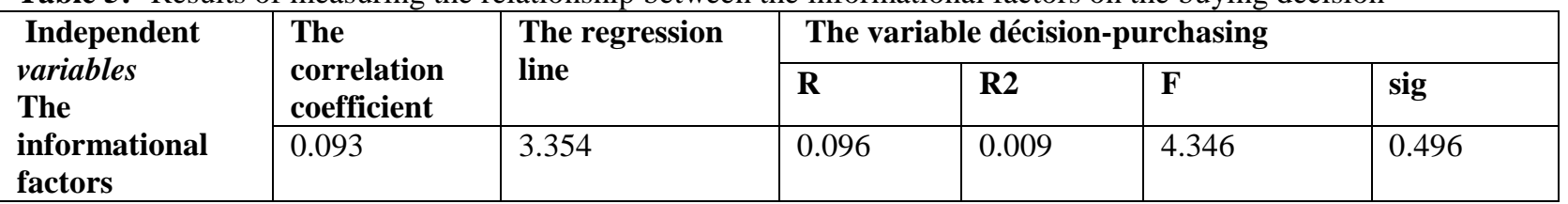

Source: the preparation of researchers and the adoption of the spss 19.

The table above shows that the binary value of the link (R) between the informational factors and the decision factors were SPV (0.096), an increase of $9.6 \%$ is a very weak link, as was the coefficient of determination $(\mathrm{R} 2=$ $0.009)$ ie $(0.09 \%)$ the change in the purchasing decision is due to the change in informational factors. Note that the significance level ( $\mathrm{Sig} 0.496)$ is greater than the level of significance $(0.05)$ This shows that there is no statistically significant differences between the decision of purchasing and informational factors, I accept the hypothesis of bad and reject any alternative hypothesis there is no statistically significant relationship between purchasing decision factors and the informational factors (x4) and the decision SPV (y) as follows and thus can be written regression equation between informational factors

$$
Y=3.354+0.093 X_{4}
$$

Hypothesis Basic key:-

There is a positive correlation significant differences between the image corporate and the purchasing decision. H0: There is no statistically significant relationship between the image corporate and the purchasing decision H1: There are significant differences between the image corporate and the purchasing decision

Table 6:- Results of measuring the relationship between the image corporate and the purchasing decision

\begin{tabular}{|l|l|l|l|l|l|l|}
\hline $\begin{array}{l}\text { Independent } \\
\text { variables } \\
\text { corporate image }\end{array}$ & $\begin{array}{l}\text { The } \\
\text { correlation } \\
\text { coefficient }\end{array}$ & The regression & \multicolumn{4}{|l|}{ The variable décision-purchasing } \\
\cline { 3 - 7 } & 0.058 & 3.479 & $\mathbf{R}$ & $\mathbf{R 2}$ & $\mathbf{F}$ & sig \\
\cline { 2 - 7 } & & 0.041 & 0.002 & 9.719 & 9.719 \\
\hline
\end{tabular}

Source: the preparation of researchers and the adoption of the spss 19. 
Comment: The above table shows that the bilateral link value $(\mathrm{R})$ between the corporate image and purchasing decision was (0.041), an increase of $4.1 \%$ is a very weak link, as was the coefficient of determination $(\mathrm{R} 2=0.002)$ that is $(0.2 \%)$ of change purchasing decision in the decision due to the change in the corporate image . Note that the significance level (Sig0.769) is greater than the level of significance (0.05) This shows that there is no significant differences between the purchasing decision and corporate image, we accept the hypothesis of bad and reject any alternative hypothesis there is no statistically significant relationship between purchasing decision and corporate image and thus can be written regression equation between the corporate image (x) and the purchasing decision (y) as follows

$$
Y=3.479+0.058 X
$$

\section{Conclusion:-}

Through this analytical study and exploit the field experiences and after friction with company customer "'Djezzy " can say that ""Djezzy "corporate no longer has a good standing among customers for the time being through the current conditions that led to the decline in its image in the minds of consumers (béchar province) and that influenced their Purchase Decision and through our study based on the outputs of spss show us that a weak correlation coefficient, which is estimated at $0.041 \mathrm{R}=$, which assured us that there is no impact to the corporate image on the decision of purchasing the final consumer and explain to us by introducing a questionnaire that promotional offers big role in improving the corporate image in the minds of consumers.

Health the hypothesis that the image on the Enterprise is the main and influential only motivation to make the consumer chooses a commodity without the other, the picture is never the sole motive but there are other motives a .ffect consumer behavior...

\section{References:-}

1. 'In the site//www.businessdictionary.com/definition/corporateAvailable at:17-01-2017

2. iiEman Mohamed Abd-El-Salam, AymanYehiaShawkyandTawfik El-Nahas, The impact of corporate image and reputation on service quality, customer satisfaction and customer loyalty: testing the mediating role. Case analysis in an international service company, The Business \& Management Review, Vol.3 Number-2, January 2013,p178

3. iii Bouchet, Dominique. 2000. "Hvad er "corporate image"? Hvader "corporate identity omdet?"Version fra den 26. Marts 2000. Pp. 4-13

4. iv Maria-Cristiana munthiu, The buying decision process and types of buying decision behaviour In the site:ww.uamsibiu.ro/.../2009\%20vol2\%20no4\%20EcSci\%2010.,Available at. 17-01-2017 